\title{
Understanding Fatherhood in Greece: Father's Involvement in Child Care ${ }^{1}$
}

\author{
Katerina Maridaki-Kassotaki ${ }^{2}$ \\ Harokopio University, Greece
}

\begin{abstract}
The present study aims to depict a picture of Greek fathers concerning their involvement in family and childcentered tasks over the first year of the child. Eighty fathers from rural areas with low educational and occupational status and eighty fathers from urban districts with high educational and occupational status were asked to talk about their own perceptions of fatherhood and also their participation into two parenting commitments: (a) preparations before and after the birth of the child and (b) involvement in play with the child and a variety of daily child-care tasks. The results show that fathers in urban regions were more involved in these activities than their counterparts in rural areas. All fathers valued fatherhood as a pleasant experience. Many fathers, however, stated that child-rearing responsibilities cause them a lot of psychological strain. The results are discussed in relation to the division of roles between spouses in Greek families.
\end{abstract}

Key words: fatherhood; child care; fathers' perceptions; child-rearing tasks.

\section{Compreendendo a Paternidade na Grécia: O Envolvimento do Pai no Cuidado de Bebês}

\begin{abstract}
RESUMO - O presente estudo descreve o envolvimento do pai grego com a família e as tarefas de cuidados da criança, durante o seu primeiro ano de vida. Oitenta pais de zona rural, de nível educacional e status ocupacional baixos, e 80 pais de zona urbana, de nível educacional e status ocupacional altos, falaram sobre as suas percepções de paternidade e de sua participação em duas das responsabilidades dos pais: (a) a preparação antes e após o nascimento de um bebê e (b) o envolvimento em brincadeiras e em uma variedade de tarefas rotineras de cuidados da criança. Os resultados mostram que os pais provenientes de áreas urbanas se envolviam mais nessas atividades que os pais de áreas rurais. Todos os pais valorizaram a paternidade como uma experiência agradável; muitos deles, entretanto, afirmaram que as responsabilidades de educar a criança causaram-lhes muita tensão psicológica. Os resultados são discutidos em relação à divisão de papéis entre o marido e a esposa, nas famílias gregas.
\end{abstract}

Palavras-chave: paternidade; cuidados da criança; percepção do pai; tarefas de educação da criança.

The mother-child relationship has been regarded by most theorists as unique and more important than any other relationships (e.g., Lamb, 1975). It held the central position in a large number of studies within psychology until late 1950s. The ascendant interest in fathers in recent years is reflected on the bulk of research on fathers' involvement in family life. As an indication, it has been estimated that about 700 psychology journal articles on fathers are published per year in English speaking countries only (Dessen \& Lewis, 2000).

The resurgent research on men's family roles is a result of a number of social changes which have influenced the traditional male and female roles in most countries. These changes comprise the female movement in 1960-70s, the increase in the number of women entering the labor force,

1 I would like to express my appreciation to the one hundred and sixty fathers who agreed so willingly to participate in this study. My appreciation and thanks also go to Maria Auxiliadora Dessen and an anonymous reviewer for their helpful detailed comments on earlier versions of this paper.

2 Address: Correspondence concerning this article should be addressed to Katerina Maridaki-Kassotaki. 41, Argirokastou str., 15235 Ano Vrilissia, Athens, Greece. E.mail: Kmaridaki@hua.gr the increase of one-parent families, the decrease of married couples, the decrease in the number of children in nuclear families, and the spread of the child-centered ideology (Kallinikaki, 1992).

The majority of studies conducted on fathers thirty years ago attempted to answer questions related mainly to their role in children's moral development and sex-role adoption. Later research placed great emphasis on father-child relationships and particularly on paternal influence on the child's cognitive growth (Lamb, 1976a). Thus there is evidence to suggest that fathers' participation in the family is related to the cognitive competence of boys and not so much of girls. It has also been found that the absence of fathers before the age of five has a negative impact on the intellectual functioning of young boys (Radin, 1976; Weinraub, 1978).

Fathers' greater interest in daily routines of family life and child-rearing, which has brought about a change in the division of paternal roles, has been the focus of interest in a large number of studies carried out in different parts of the world in recent years. In Australia, it has, for example, been found that fathers contribute to the care of their offsprings equally with mothers in fewer than two percent of families and fathers who are highly engaged in child care are less 
than ten percent (Russell \& Radojevic, 1992). In another study (Holland, 1996), forty Australian fathers' perceptions of fatherhood were examined. It was indicated that seventy percent of them valued fatherhood experiences related to sharing attention and experiences with their children. They also perceived their involvement to be in meeting their children's emotional needs.

A survey study carried out among 100 married mothers in another part of the world (Sao Paulo, Brazil) showed that forty-five percent of the mothers had the responsibility of household and child-rearing routines on their own. Thirtyfive percent of them reported that they shared these responsibilities with their husbands (Kishimoto \& Haddad, 1995).

A large scale survey study conducted by Osborn and Morris (as cited in Lewis, 1997), among 13,000 English fathers of five-year-old children, revealed that approximately 3,000 fathers had never committed themselves to the following tasks: (a) putting the child to bed, (b) taking or collecting the child from school, (c) looking after the child without the mother, and (d) reading to the child. Only 520 of the participating fathers had performed all four from the above tasks. A later study carried out in England by Lewis (1986) focused on 100 men's own descriptions of their experiences as fathers in a period between the child's birth and his first birthday indicated that fathers' participation in the daily care of their infants fits the routine of their wives. The study established that the time fathers spend with their children varies as a result of their cultural environment and the quality of relationship with their spouses.

The above research and a number of relevant recent studies performed in Western countries (Seward \& Yeatts, 1997; see also Lamb, 1976b, 1987, 1997; Lewis, 1997) suggest that mothers are still in charge of child care with fathers helping out and gradually becoming more involved in the care of their children. There is, however, a good deal of evidence related to studies performed in Eastern countries which attests to involvement of men in child care responsibilities (Hewlett, 1987).

Research dealing with Greek men's participation in parenthood and especially with their responsibilities for childrearing is very limited. So far, we know very little about the contribution of Greek men to family-life activities and especially to the care of their young offsprings. Thus, our understanding of fatherhood in Greece remains unclear. There are only a few studies addressing issues related to fatherhood and these are reviewed below.

One of them, based on the descriptions of twenty three first-time fathers of their commitments to family tasks, attempts to gain some insight into how these fathers experience the pregnancy of their wives, the time after mother and baby return home from hospital, and during the first months of the child's life (Dragonas \& Naziris, 1995). The accounts elicited from the fathers describe their involvement in such life events as an important and constructive experience, which is largely determined by their individual characteristics and past experiences.
Another study (Krasanakis, 1991) examines how 400 unmarried university students coming from rural areas perceive the participation of their fathers and paternal grandfathers in family life. The evidence provided in this study shows that students think that their fathers are more involved in fatherhood than their paternal grandfathers. Students also state that their fathers, as compared to their paternal grandfathers, punish less frequently their children, approve the decisions and choices they make, and encourage them in taking initiatives.

Perhaps the most severe limitation to the available restricted amount of research literature in Greek parenthood is the absence of a study examining the participation of fathers in a range of child care routines. The present study aimed to address this issue. It examined (a) men's impressions of their wives' pregnancy, (b) fathers' behavior when mother and baby are at hospital and after home-coming, (c) parental involvement in child care and housework over the first months of the child, (d) the development of father-child relationship during play, and (e) fathers' own perceptions of parenthood. The investigation of the above goals allows us to depict the picture of the Greek father as regards his involvement in family and child care during the first year of the child's life. Furthermore, it will enable us to compare the role of Greek fathers in family practices with that of fathers from different cultures.

\section{Method}

\section{Sample}

The sample comprised 160 fathers out of 179 approached in urban and rural communities. Nineteen refused to participate in the study. All fathers had a first or a second child who was about one year of age at the time of testing. Eighty fathers lived in rural areas and the rest of them in urban districts. Fathers from rural areas were inhabitants of villages and small towns in the island of Crete, Central and Northern Greece. Men from urban regions were from the cities of Athens and Iraklion. Fathers were selected at random from the lists of registered births kept in the Registrar Office of the place of their residence. Sixty five out of eighty men in the rural region were primary and lower secondary school graduates, fourteen had finished upper secondary school and only one was found to have a technical school degree. The majority of them worked in their own fields, a small number was skilled workers and very few were in the trade. Most of the men $(n=64)$ from urban areas held a university or technical institution degree, 10 had graduated upper secondary school and six had finished a private technical institute. The majority of them were civil workers (school teachers, bank clerks, etc.), some were lawyers and doctors and a few were tradesmen. Both spouses from urban districts were employed outside the home. The majority of wives from urban regions (78\%) were engaged in paid employment or helped out their husbands at work. 


\section{Procedure}

Fathers were asked to participate in the study with a letter mailed one month before an interview with them. Phone calls were made as reminders to those who had not responded. All men were willing to help and showed a great interest in asking questions about several aspects of parenthood. Most of them, especially those living in the area of Athens, expressed their pleasure about the study and said that it was about time fathers were taken notice. The interview took place in the living room of their house or in a quiet place at work (e.g., office). Fathers were interviewed alone, so that the interview would not be distracted and they would not be influenced by the presence of others. The interviewer asked fathers a series of questions from a questionnaire and wrote down their answers. It was necessary for the interviewer to complete the questionnaires as some of the fathers had reading problems or were reluctant to do it. Fathers' replies were also tape-recorded.

The questionnaire consisted of five sections. The first comprised questions concerning personal data (e.g., occupational and educational status, child's name, the hours of their daily work and the time they are at home with their children and spouses per day). The second consisted of questions related to men's attitudes toward their wives during pregnancy. In the third section fathers' involvement in the preparations for the arrival home of baby and mother was examined. The fourth section dealt with fathers' participation in daily child-care activities and play. Finally, the fifth section examined men's own perceptions about fatherhood.

\section{Results}

The presentation of results is divided into five distinct parts. The first describes men's impressions of their wives' pregnancy. Fathers' behavior after the baby arrives home is discussed in Part 2. Part 3 examines the development of men's participation in the daily care of their young children. The development of the father's relationship with his child during play is examined in Part 4. Finally, the last part presents fathers' own perceptions of fatherhood.

\section{Prospective fathers' attitudes toward their pregnant spouses}

Table 1 shows the answers of fathers to the questions related to how they felt when they heard that their wives were expecting a baby. The announcement of pregnancy evoked positive feelings such as joy, pleasure, happiness, tenderness, love, affection and pride among all fathers. The majority of fathers (96.2\% from urban districts and $88.7 \%$ from rural areas) reported feelings of joy and happiness. Men in the rural regions $(61.2 \%)$ were significantly more proud of becoming fathers than men $(15 \%)$ from urban districts, $X^{2}(1,160)=$ $36.27, p<.001$.

It is interesting to note that men in urban areas (45\%), as compared to men in rural areas $(10 \%)$, showed greater-
Table 1

Men's Responses to the Question: "How did you Feel When you Heard That Your Wife was Expecting a Baby?"

\begin{tabular}{lcccc}
\hline & \multicolumn{4}{c}{ Community type } \\
\cline { 2 - 5 } Response category & Urban $(\mathrm{n}=80)$ & Rural $(\mathrm{n}=80)$ \\
\cline { 2 - 5 } & $\mathrm{n}$ & $\%$ & $\mathrm{n}$ & $\%$ \\
\hline Joy, happiness & 63 & 78.2 & 71 & 88.7 \\
Pleasure, tenderness, affection, love & 56 & 70 \\
Pride & 12 & 15 & 49 & 61.2 \\
\hline
\end{tabular}

though not satisfactory- interest in reading books and magazines on pregnancy, child care and parenthood in order to get better informed about pregnancy and child delivery, $X^{2}(1$, $160)=20.6, p<.001$. Leaflets were the most popular reading materials because, according to men's accounts, they contain brief information and as such they are quicker to read. Only eight of the urban and one of the rural males reported attendance of parentcraft classes. Both reading about pregnancy and attending antenatal classes were regarded by prospective fathers, even by those who mentioned participation in these activities, as "women's commitments" during pregnancy.

The finding that men in the rural community were less likely to read about child-rearing may have stemmed from their more limited education, compared to the city men. It could also stem from their stronger support for more traditional views of male and female roles found in rural than urban areas.

\section{Fathers' behavior during their wives' stay in hospital and after the return home of mother and child}

Fathers from urban regions spend more time on preparation for the home-coming of child and mother than men living in rural areas, though their involvement is limited (35\% living in cities vs. $7.5 \%$ living in rural areas; $X^{2}(1,160)=18.1, p<$ $.001)$. There also appears to be a difference in the amount of time spent on housekeeping a few days after the birth of the child. Thirty five urban and four rural males claimed that took over considerable responsibility for the running of the household during this period (a difference that is statistically significant; $\left.X^{2}(1,160)=35.6, p<.001\right)$. The accounts of fathers from rural areas suggest that the availability of close relatives (mainly mothers' female relatives) was the reason why they did not contribute to housekeeping. Some of them noted that they were willing to assist in housework and some child care but got discouraged by their wives and close relatives. It is likely that these men do not use the above reason as an excuse for their avoidance as the majority of mothers in the rural community reported that they do not want their husbands to get involved in child-rearing and house activities because they lack the appropriate skills for such tasks. Most of the men living in urban districts who take responsibilities for domestic routines and child care claim that they do so, because they do not have any other alternatives (e.g., relatives to help). This is the reason why the majority of them (58 out of 80 ) took some time off from work 
after the arrival of the baby. A few men living in cities mentioned that they contribute to housekeeping during this period because they want to allow their wives time to rest.

\section{Parents' contribution to child care over the first year of the child's life}

Table 2 clearly illustrates the responses of fathers to the question concerning their participation in daily child care over the first year. As shown in the table, fathers' commitment to different babies' routines vary considerably across different communities. An interesting finding is that the vast majority of fathers in the rural community are not involved in most of the daily child-care tasks. Men from cities seem to be contributing more, but not very largely. A greater number of urban $(26.2 \%)$ than rural (10\%) men claim that they occasionally bottle-or-solid feed their babies. This difference is statistically significant; $X^{2}(1,160)=7.2, p<.01$. Similarly, more fathers from urban areas take daily responsibility for feeding the baby $\left(12.5 \%\right.$ urban and $1.2 \%$ rural males; $X^{2}(1$, 160) $=7.9, p<.01)$.

Another discernible pattern in Table 2 is that the vast majority of men from rural areas appear to avoid tasks like nappy changing, night waking, bathing, and putting the child to bed. The participation of city men in these tasks is higher than that of their counterparts from rural districts, $X^{2}(1,160)$ $=5.9, p<.05$ for night waking; $X^{2}(1,160)=20.1, p<.001$, for changing nappies; $X^{2}(1,160)=52.2, p<.001$, for putting the child to bed; $X^{2}(1,160)=38.3, p<.001$, for bathing. Feeding and putting to bed are the most popular activities among those who become involved in them.

The participation of fathers from the rural community in child care and housekeeping does not seem to relate to the number of hours they are available at home. It rather has to do with social stereotypes concerning the division of paternal roles. When, for example, men living in rural areas were asked to justify their responses, they said that child care routines have to be undertaken by women only. Their replies were phrased like these tasks are women's not men's jobs. Most of the city men who actively participated in the above activities reported that they "had" to do so while their wives

Table 2

Parental Involvement in the Daily Child Care Over the First Year of the Child's Life

\begin{tabular}{lrrrr}
\hline & \multicolumn{5}{c}{ Community type } \\
\cline { 2 - 5 } Response category & Urban $(\mathrm{n}=80)$ & Rural $(\mathrm{n}=80)$ \\
\cline { 2 - 5 } & $\mathrm{n}$ & $\%$ & $\mathrm{n}$ & $\%$ \\
\hline Feed the baby occasionally when & 21 & 26.2 & 8 & 10 \\
my wife can not do so & & & & \\
Bottle-or solid-feed the baby daily & 10 & 12.5 & 1 & 1.2 \\
When the baby cries in the night & 8 & 10 & 1 & 1.2 \\
my wife wakes up & & & & \\
Change nappies & 23 & 28.7 & 2 & 2.5 \\
Put the child to bed & 48 & 60 & 5 & 6.2 \\
Bathe the child & 35 & 43.7 & 2 & 2.5 \\
\hline
\end{tabular}

were out to work. Only nine fathers answered that they enjoyed being involved in these tasks.

\section{Fathers as playmates}

Analysis of the data concerning fathers' involvement in play during the first year of the child seem to reveal that they place higher priority on play than they place on activities related to child care. The time they spend playing with their children, as shown in Table 3, varies from 30 minutes to 1-2 hours mainly during weekends. The majority $(41.2 \%)$ of fathers in the rural community appear to spend daily less time to play with their children than fathers $(15 \%)$ in the cities although they mention that they are at home for a longer time, $X^{2}(1,160)=13.64, p<.001$. Furthermore, they devote to their children less time to play over weekends than their counterparts in cities; $60 \%$ in the urban versus $20 \%$ in rural areas played for at least 30 minutes to 2 hours on weekends, $X^{2}(1,160)=26.67, p<.001 ; 78.7 \%$ in urban vs. $36.2 \%$ in rural areas played for at least 30 minutes to 1 hour on weekends, $X^{2}(1,160)=29.57, p<.001$.

The descriptions of the fathers revealed that they prefer to occupy their children with active play. Chasing and hide and seek are reported to be the most popular active physical plays they prefer to engage their children. Many fathers commented that play is an amusing activity for them which becomes a great fun around the child's first birthday. Their accounts suggested that during this period children are more responsive than they were during the first months of their lives and thus interaction with them is easier to be achieved. They also noted that play is a good way to build up and develop close relationships with their children.

Table 3

Average Amount of Time Fathers Play With Their One-Year-Olds per day and Weekends

\begin{tabular}{lrrrr}
\hline \multirow{3}{*}{ Time } & \multicolumn{4}{c}{ Community type } \\
\cline { 2 - 5 } & Urban $(\mathrm{n}=80)$ & R ural $(\mathrm{n}=80)$ \\
\cline { 2 - 5 } & $\mathbf{n}$ & $\%$ & $\mathbf{n}$ & $\%$ \\
\hline 30 minutes to 2 hours per day & 33 & 41.2 & 12 & 15 \\
30 minutes to 2 hours on weekends & 48 & 60 & 16 & 20 \\
30 minutes to 1 hour on weekends & 63 & 78.7 & 29 & 36.2 \\
\hline
\end{tabular}

Table 4

Parents' Perceptions About Fatherhood

\begin{tabular}{lcrcc}
\hline & \multicolumn{4}{c}{ Community type } \\
\cline { 2 - 5 } Response category & Urban ( $\mathrm{n}=80)$ & Rural & $(\mathrm{n}=80)$ \\
\cline { 2 - 5 } & $\mathrm{n}$ & $\%$ & $\mathrm{n}$ & $\%$ \\
\hline It is a pleasant experience & 76 & 95 & 68 & 85 \\
It is a rejuvenating experience & 22 & 27.5 & 48 & 60 \\
Evokes feelings of love, affection & 72 & 90 & 61 & 76.2 \\
and care for the child & & & & \\
It is a lot of strain (psychological & 69 & 86.2 & 64 & 80 \\
and financial) & & & & \\
It disrupts my life-style & 68 & 85 & 11 & 13.7 \\
It makes me feel a "real man" & 34 & 42.5 & 65 & 81.2 \\
\hline
\end{tabular}




\section{Fathers' own perceptions of parenthood}

Fathers were asked to discuss at length their experiences about parenthood. As shown in Table 4, the positive feelings found in their replies rather overweigh the negative ones. It appears, however, to be differences and commonalities between the members of the two social groups that are examined as regards their descriptions of fatherhood.

The majority of both urban and rural males valued fatherhood as a pleasant experience. Men from cities (27.5\%) were significantly less likely to claim that fatherhood is a rejuvenating experience than men $(60 \%)$ in the rural community, $X^{2}(1,160)=17.17, p<.001$. A greater number of city men $(85 \%)$ than men in rural areas $(13.7 \%)$ reported that undertaking child-care responsibilities has a rather negative impact on them, $X^{2}(1,160)=81.2, p<.001$. Such a position is reflected on their replies suggesting that fathering disturbs their life-styles. A possible explanation for this is the relatively high participation of city men in family-centered activities during the first months of the child's life which are tiring and time-absorbing.

It is worth mentioning a contradiction found in fathers' responses. While they refer to fatherhood as a period during which they experience feelings of love, tenderness, and care for their children, the vast majority of them claim that their new roles cause a lot of psychological and financial strain to them. This strain was reported to be a result of their increased novel commitments to family life and child-rearing.

An interesting finding was that men living in rural districts were significantly more likely to place fatherhood within the traditional stereotype of masculinity ( $42 \%$ in urban and $81 \%$ in rural areas, $\left.X^{2}(1,160)=25.5, p<.001\right)$. On their accounts, becoming a father is identical to being able to confirm one's masculine nature, and in their own words, to becoming a "real man."

\section{Discussion}

The results presented in this study provide clear support for the view that the participation of Greek fathers in family and child-care activities before the birth of the child and during the first year of his/her life is associated with community type (urban vs. rural). They also suggest that Greek fathers, regardless of the type of their region, value fatherhood as a pleasant experience which causes them a lot of psychological strain due to the enhanced commitments associated with the arrival of the child.

Evidence that fathers from rural areas with low academic achievements and occupational status are less likely to contribute to child care practices than fathers living in urban areas with high educational and occupational status was apparent in the analysis of two parenting commitments which were selected for scrutiny: (a) preparations before and after the birth of the child (fathers' attitudes towards their pregnant wives and their behavior during their wives' stay in hospital and after the return home of mother and baby) and (b) involvement in play with the child and a variety of daily child-care tasks such as feeding, putting the child to bed, bathing, etc.

An issue that is important to mention is that community differences in fathering roles do not necessarily suggest that the involvement of urban fathers in family is satisfactory or equal to that of mothers. The results indicate that more men in cities are engaged in play and daily child care tasks. Their role, however, is secondary as they appear to help out their wives who seem to take on the majority of domestic and child-care routines, according to their husbands' accounts. This finding is incongruent with the views expressed by most of the husbands participating in the study that they should share family practices equally with their wives.

The evidence emerging from the present study complies with findings from studies reported earlier in this paper which attest to the growing involvement of men in family activities in many western countries. Furthermore, it expands previous research on the division of family responsibilities in Greek middle-class which indicates the participation, though limited, of Greek middle-class husbands to household and child care (Kalkavoura, 1994).

An interesting result to discuss is that some of the fathers who were willing to undertake child care responsibilities had often been discouraged to do so by their wives and close relatives who helped out. The accounts of the husbands suggest that women justified this kind of behavior by saying that men lack the "proper" skills for child care tasks. Such a view is reflected on the work of the sociologist Alice Rossi supporting the position that paternal roles are biologically determined. As Rossi (cited in Dessen \& Lewis, 2000) puts:

women have a headstart in easier reading of an infant's facial expressions, smoothness of body motions, greater ease in handling a tiny creature with tactile gentleness, and in soothing through a high, soft rhythmic use of the voice. By contrast, men have tendencies more congenial to interaction with an older child, with whom rough and tumble play, physical coordination, teaching of object manipulation is easier and more congenial. (pp. 1-2)

Fathers from urban areas, who were committed to family activities, reported that the tasks they were involved in are mainly "women's" responsibility. The majority of them noted that they had to assist in child care when their wives were out at work or ill and emphasized that they were doing things which were not their own responsibility. In this way, men's participation may be characterized, in the words of Rapoport and Rapoport (1971), as an "act of good will towards the wife." This may be the reason why most of the fathers living in cities viewed fathering as a tiring experience that disrupts their life-style.

All fathers, however, seemed to welcome the announcement of the pregnancy of their wives by mentioning that it caused the experience of positive feelings such as pleasure, affection, tenderness, happiness, and even pride. It is worth noting that pride was most frequently reported by men in the rural community. When asked to justify their responses, these men related this feeling to the fact that their wives' 
pregnancy "validated their maleness." Taken together, this position and also the view that prevailed in men's accounts according to which "fatherhood confirms their masculine identities", one can argue that men from rural areas are more likely to place fatherhood within the traditional stereotype of social context which attributes to men an authoritarian role within the family in addition to that of the "breadwinner" and family provider.

How can the above pattern of findings be explained? The division of roles among spouses in Greek families could possibly provide an account for these findings. In 1950s, Greek women stayed inside and accomplished their "mission" by undertaking the household tasks, offering their services to their husband and nurturing the children. This role has changed nowadays. Most of Greek women work outdoors to support their families. Despite this change, household tasks are still considered as "women's responsibilities" (Mousourou, 1984, 1985, 1993) and the roles of the spouses in Greek families in recent years, regardless of social class, are differentiated as follows: The husbands work outside the house and provide the family with material goods. They are expected to play a minor role in the rearing of the children. Wives, unlike their husbands whose main focus is on achievement, undertake the burden of domestic and child-rearing responsibilities even if they work outside (Katakis, 1984; Rapoport, Fogarty, \& Rapoport, 1982).

The available data related to the participation of men from the rural community in child care reflect the above descriptions of sex roles in Greek families more than the data related to the involvement of men living in cities. As shown, men from rural areas are less likely to commit themselves to household and child care routines, and thus they follow the traditional pattern of sex-roles. On the contrary, city men appear to have started to accept a new role within the family that of the supporter of the wife in child-rearing activities, though, as they suggest, they do not consider it as a "male" role. The distinct differentiation in the family roles between men in rural and urban areas may therefore lead to the claim that fatherhood is a process highly determined by the needs created in one's cultural and social environment. Such a claim has received a large support by many theorists (e.g., Mead, 1950/1962).

To conclude, the present study has attempted to depict the picture of Greek fathers as regards their involvement in family and child-care activities during the first year of the child's life. From the reported evidence fathers living in urban districts with high educational and occupational status appear to contribute more to child-rearing tasks compared to their counterparts coming from rural regions with lower educational and occupational status. Despite the higher involvement of city men in child care routines, women seem to take on most of the home workloads. Based on the husbands' accounts which suggest that they are not allowed by their wives to undertake "female" activities, one could argue that if wives give up their traditional way of thinking about family responsibilities and claim higher paternal participation, new role patterns involving equal sharing of activities between spouses at Greek homes will emerge.

\section{References}

Dessen, M. A., \& Lewis, C. (2000). Parental influences in family life of preschoolers with unemployed and employed fathers (Report No. AI/CNPq 523059/96-5). Brasília, DF, Brazil: Family Development Laboratory, University of Brasília.

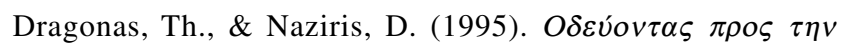
$\pi \alpha \tau \rho o ́ \tau \eta \tau \alpha$ [Becoming a father]. Athens: Exantas.

Hewlett, B. S. (1987). Intimate fathers: Patterns of holding among Aka pygmies. In M. E. Lamb (Ed.), The father's role: Crosscultural perspectives (pp. 295-320). Hillsdale, NJ: Lawrence Erlbaum.

Holland, A. (1996). Dads, data and discourse: Theory, analysis and interpretation in parenting research. Australian Research in Early Childhood Education, 1, 254-263.

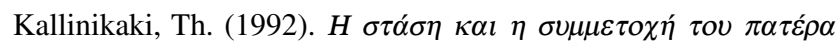

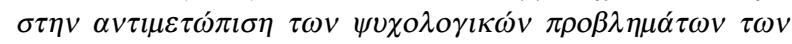
$\varepsilon \varphi \eta ́ \beta \omega \nu$ [The attitude and involvement of father in coping with the psychological problems of adolescents]. Unpublished doctoral dissertation, University of Athens, Greece.

Kalkavoura, C. E. (1994). The division of family responsibilities in middle-class Greek families. Unpublished doctoral dissertation, University of Reading, UK.

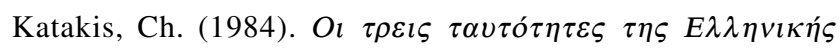

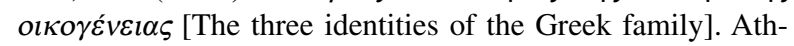
ens: Kedros.

Kishimoto, T., \& Haddad, L. (1995, September). Modern family in context: The case of Brazil. Paper presented at the European Conference on the Quality of Early Childhood Education, Paris.

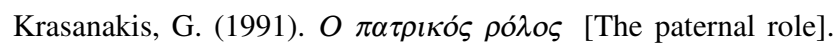
Athens: Grigoris.

Lamb, M. E. (1975). Fathers: Forgotten contributors to child development. Human Development, 18, 245-266.

Lamb, M. E. (1976a). The role of the father: An overview. In M. E. Lamb (Ed.), The role of the father in child development (pp. 163). New York: Wiley.

Lamb, M. E. (Ed.). (1976b). The role of the father in child development. New York: Wiley.

Lamb, M. E. (Ed.). (1987). The father's role: Cross-cultural perspectives. Hillsdale, NJ: Lawrence Erlbaum.

Lamb, M. E. (Ed.). (1997). The role of the father in child development $\left(3^{\text {rd }}\right.$ ed.). New York: Wiley.

Lewis, C. (1986). Becoming a father. Milton Keynes: Open University Press.

Lewis, C. (1997). Fathers and preschoolers. In M. E. Lamb (Ed.), The role of the father in child development ( $3^{\text {rd }}$ ed., pp. 121142). New York: Wiley.

Mead, M. (1962). Male and female. Harmondsworth: Pelican. (Original work published 1950)

Mousourou, L. M. (1984). H $\varepsilon \lambda \lambda \eta v \imath \kappa \eta ́ ~ O \imath \kappa o \gamma \varepsilon ́ v \varepsilon \imath \alpha$ [The Greek family]. Athens: Goulandris-Horn Foundation.

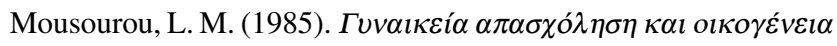
$\sigma \tau \eta v E \lambda \lambda \alpha ́ \delta \alpha \kappa \alpha \iota \alpha \lambda \lambda o v$ [Female employment and family in Greece and abroad]. Athens: Estia.

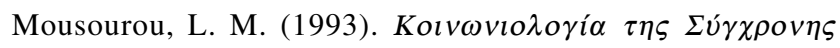

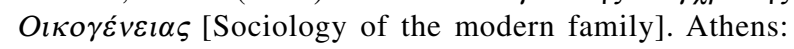
Gutenberg. 
Radin, N. (1976). The role of father in cognitive, academic, and intellectual development. In M. E. Lamb (Ed.), The role of the father in child development (pp. 237-276). New York:Wiley.

Rapoport, R., \& Rapoport, R. N. (1971). Dual career families. Harmondsworth: Penguin.

Rapoport, R. N., Fogarty, M. P., \& Rapoport, R. (1982). Families in Britain. London: Routledge \& Kegan Paul.

Russell, G., \& Radojevic, M. (1992). The changing role of fathers? Current understandings and future directions for research and practice. Infant Mental Health Journal, 13, 296-311.
Seward, R., \& Yeatts, D. E. (1997, November). Fathers caring for children: Research and resources. Paper presented at the Annual Conference of the National Council on Family Relations, Crystal City, USA.

Weinraub, M. (1978). Fatherhood: The myth of the second class parent. In J. H. Stevens \& M. Matthews (Eds.), Mother/child and father/child relationships. Washington, DC: National Association for the Education of Children. 